\title{
NON-CONFORMABLE INTEGRAL INEQUALITIES OF CHEBYSHEV-PÓLYA-SZEGÖ TYPE
}

\author{
SaAd Ihsan Butt, Ahmet Ocak Akdemir, Praveen Agarwal \\ AND DUMITRU BALEANU
}

Abstract. Inequality studies involving new integrals and derivatives have been carried out recently. This article designed as follows, the results were obtained by using the non-conformable fractional integral operators to provide new inequalities of Polya-Szegö and Chebyshev type. Some special cases have been considered for our main findings.

Mathematics subject classification (2020): 26A33, 26D10, 26D15.

Keywords and phrases: Chebyshev inequality, Polya-Szegö type inequalities, non-conformable integral operators.

\section{REFERENCES}

[1] P. M. Guzman, G. Langton, L. L. Motta, J. Medina and J. E. Napoles V., A New definition of a fractional derivative of local type, J. Math. Anal. 9 (2) (2018), 88-98.

[2] J. E. Napoles Valdes, P. M. Guzman, L. M. Lugo, Some New Results on Non-conformable Fractional Calculus, Adv. Dyn. Syst. Appl. 2018, 13, 167-175.

[3] J. E. Napoles Valdes, J. M Rodriguez, J. M. Sigarreta, New Hermite-Hadamard Type Inequalities Involving Non-Conformable Integral Operators, Symmetry 11 (9): 1108, 2019.

[4] P. L. Chebyshev, Sur les expressions approximatives des integrales definies par les autres prises entre les memes limites, Proc. Math. Soc. Charkov 2 (1882), 93-98.

[5] Z. Dahmani, O. Mechouar, S. Brahami, Certain inequalities related to the Chebyshev functional involving a type Riemann-Liouville operator, Bull. Math. Anal. Appl. 3 (2011), 38-44.

[6] G. Pólya, G. Szegö, Aufgaben und Lehrsatze aus der Analysis, Band 1, Die Grundlehren der mathmatischen, Wissenschaften 19, J. Springer, Berlin, 1925.

[7] S. S. Dragomir, N. T. Diamond, Integral inequalities of Grüss type via Polya-Szegö and ShishaMond results, East Asian Math. J. 19 (2003), 27-39.

[8] I. Podlubny, Fractional Differential Equations, Mathematics in Science and Enginering, 198, Academic Press, New York, London, Tokyo and Toronto, 1999.

[9] A. A. Kilbas, H. M. Srivastava, J. J. Trujillo, Theory and applications of fractional differential equations, North-Holland Mathematics Studies, 204, Elsevier Sci. B. V., Amsterdam, 2006.

[10] S. K. Ntouyas, P. Agarwal, J. Tariboon, On Polya-Szegö and Chebyshev type inequalities involving the Riemann-Liouville fractional integral operators, J. Math. Inequal. 10 (2016), 491-504.

[11] E. SET AND B. ÇELIK, Certain Hermite-Hadamard type inequalities associated with conformable fractional integral operators, Creative Math. Inform. 26 (2017), 321-330.

[12] E. Set, A. O. AKdemir, I. Mumcu, The Hermite-Hadamard's inequaly and its extentions for conformable fractional integrals of any order $\alpha>0$, Creative Math. Inform. 27 (2018), 197-206.

[13] E. SET, A. GözPInAR, I. Mumcu, The Hermite-Hadamard Inequality for s-convex Functions in the Second Sense via Conformable Fractional Integrals and Related Inequalities, Thai J. Math., 2018.

[14] A. Ekinci And M. E. Ozdemir, Some New Integral Inequalities Via Riemann Liouville Integral Operators, Applied and Computational Mathematics 3 (2019), 288-295.

[15] Z. Dahmani, L. TABharit, S. TAF, New generalisations of Grüss inequality using RiemannLiouville fractional integrals, Bull. Math. Anal. Appl. 2 (3) (2010), 93-99. 
[16] S. M. KAng, G. FARID, W. NAZEer, B. TARIQ, Hadamard and Fejér-Hadamard inequalities for extended generalized fractional integrals involving special functions, J. Ineq. Appl. 2018: 119 (2018), $1-11$.

[17] S. M. KAng, G. FARID, W. NAZEer, S. Mehmood, $(h, m)$-convex functions and associated fractional Hadamard and Fejér-Hadamard inequalities via an extended generalized Mittag-Leffler function, J. Ineq. Appl. 2019: 78 (2019), 1-10.

[18] G. Rahman, D. Baleanu, M. A. Qurashi, S. D. Purohit, S. Mubeen, M. Arshad, The extended Mittag-Leffler function via fractional calculus, J. Nonlinear Sci. Appl. 10 (2017), 42444253.

[19] T. O. SAlim, A. W. FARAJ, A generalization of Mittag-Leffler function and integral operator associated with fractional calculus, J. Fract. Calc. Appl. 3 (5) (2012), 1-13.

[20] M. Z. SARIKAYA, M. E. KIRIŞ, On Čebyšev-Grüss type inequalities for double integrals, TJMM, 7 (1) (2015), 75-83.

[21] E. Set, M. Z. SARIKAYA, On the generalization of Ostrowski and Grüss type discrete inequalities, Comput. Math. Appl. 62 (1) (2011), 455-461.

[22] H. M. SRIVASTAVA, Z. TOMOVSKI, Fractional calculus with an integral operator containing a generalized Mittag-Leffler function in the kernel, Appl. Math. Comput. 211 (2009), 198-210.

[23] J. V. C. Sousa, D. S. Oliveira, E. C. Oliveira, Grüss type inequality by mean of a fractional integral, J. Math. Anal. and Appl. (2017), 1-16.

[24] F. A. Aliev, N. A. Aliev and N. A. Safarova, Transformation of the Mittag-Leffler function to an exponential function and some of its applications to problems with a fractional derivative, Applied and Computational Mathematics, v. 18, n. 3, 2019, pp. 316-325.

[25] T. Abdeljawad, On conformable fractional calculus, Journal of Computational and Applied Mathematics 279 (2015), 57-66.

[26] R. Khalil, M. Al Horani, A. Yousef and M. SABABheh, A new defnition of fractional derivative, J. Comput. Appl. Math. (264) (2014), 65-70.

[27] A. O. Akdemir, A. Ekinci And E. Set, Conformable Fractional Integrals and Related New Integral Inequalities, Journal of Nonlinear and Convex Analysis, Volume 18, Number 4, 2017, 661-674. 